IZA DP No. 6034

Employment Concentration and Resource Allocation: One-Company Towns in Russia

Simon Commander

Zlatko Nikoloski

Alexander Plekhanov

October 2011 


\title{
Employment Concentration and Resource Allocation: One-Company Towns in Russia
}

\author{
Simon Commander \\ IE Business School, EBRD, \\ Altura Advisers and IZA \\ Zlatko Nikoloski \\ University College London
}

$\underset{E B R D}{\text { Alexander Plekhanov }}$

Discussion Paper No. 6034

October 2011

IZA

P.O. Box 7240

53072 Bonn

Germany

Phone: +49-228-3894-0

Fax: +49-228-3894-180

E-mail: iza@iza.org

Any opinions expressed here are those of the author(s) and not those of IZA. Research published in this series may include views on policy, but the institute itself takes no institutional policy positions.

The Institute for the Study of Labor (IZA) in Bonn is a local and virtual international research center and a place of communication between science, politics and business. IZA is an independent nonprofit organization supported by Deutsche Post Foundation. The center is associated with the University of Bonn and offers a stimulating research environment through its international network, workshops and conferences, data service, project support, research visits and doctoral program. IZA engages in (i) original and internationally competitive research in all fields of labor economics, (ii) development of policy concepts, and (iii) dissemination of research results and concepts to the interested public.

IZA Discussion Papers often represent preliminary work and are circulated to encourage discussion. Citation of such a paper should account for its provisional character. A revised version may be available directly from the author. 
IZA Discussion Paper No. 6034

October 2011

\section{ABSTRACT \\ Employment Concentration and Resource Allocation: One-Company Towns in Russia}

The paper looks at the effects of employment concentration on resource allocation with a particular focus on one-company towns in Russia defined as towns where a single company accounts for a significant share of total employment of the locality. Empirical analysis of firms' production functions indicates that companies located in one-company towns are characterised by lower marginal product of labour, higher marginal product of capital and lower overall productivity pointing towards significant labour hoarding. One-company town enterprises are also found to be financially more vulnerable. The paper argues that the dominance of natural resources in the Russian economy and employment concentration is closely linked.

JEL Classification: D24, J42, R23

Keywords: employment concentration, one-company towns, labour productivity, Russia

Corresponding author:

Simon Commander

EBRD

One Exchange Square

London EC2A 2JN

United Kingdom

E-mail: commanders@ebrd.com 


\section{Introduction}

Russia is an economy dominated by natural resources. Despite stated policy objectives of diversification, this dominance has actually increased over the past twenty years (Guriev, Plekhanov and Sonin, 2009).1 This can be attributed to the boom in natural resource prices in the 2000s and to the resource allocations that have accompanied that boom. In this paper, we look at a related-but less acknowledged-feature of the Russian economy: its legacy of concentration in employment. We argue that the dominance of natural resources and employment concentration is in fact quite closely linked, with the latter affecting the composition of natural resource revenue spending.

Although extractive industries now account for only around $11 \%$ of total value added in Russia, their true contribution is actually far higher. As much as $60 \%$ of industrial production is concentrated in related sectors, such as refining or fertilisers, while a significant share of value added in services is accounted for by trade in natural resources and trans-shipment of oil, gas and minerals (Kuboniwa, Tabata and Ustinova, 2005; World Bank, 2004). Their weight in general government revenues is over $35 \%$ and around $55 \%$ of federal government revenues. While exports have shifted away from other CIS countries towards the EU-15, the composition of Russia's export basket has remained largely unchanged since the mid-1990s with oil and gas exports continuing to dominate to all regions. As such, most economic activity is concentrated in the periphery of the product space - mainly in hydrocarbons (Hausmann and Klinger, 2007). Interestingly, while extractive industries only directly account for $1.5 \%$ of total employment; their weight in value added is many multiples that of employment.

The growth in the relative size of the natural resource sector might have been expected as the restructuring of non-resource-based Soviet-era firms and industries has played out, but the scale of shift and its apparent persistence requires explaining. In this paper we argue that part of the explanation can be traced to the way in which the inherited composition and location of output has had an impact on policy. In particular, we argue

\footnotetext{
${ }^{1}$ The Soviet Union had a seemingly well diversified economy with manufacturing accounting for over $20 \%$ of total output in the 1980s. Yet much of what were notionally non-natural resources tradables were actually only tradable within the CMEA.
} 
that concentration in employment has been an important influence on policy by accentuating the impact on relative prices driven by a sharp appreciation in the real exchange rate through the composition of spending. This reflects the underlying sensitivity of Russian governments to the risk of mass unemployment; a sensitivity that, paradoxically, has likely been heightened by the absence of an unemployment insurance programme offering reasonable replacement rates.

To get a sense of why employment and, in particular, employment concentration has mattered, it should be noted that pre-transition, in 1989, with the exception of the wider region around Moscow, between $25-75 \%$ of industrial employment in each region was concentrated in industries that had four or fewer firms in that region (Brown, Ickes and Ryterman, 1994). Further, even when a plurality of firms was operating in a locality, these were often within the same sector, resulting in many local economies being dependent on one particular industry.

This legacy has not been quick to wither away. A recent estimate has suggested that onecompany towns - particularly severe instances of employment concentration that were commonly created for strategic, military or economies-of-scale reasons - still exceed 400 and account for over $12 \%$ of Russia's population. ${ }^{2}$ Low labour mobility within Russia has further impeded restructuring of these entities and tended to sustain these loci of employment concentration. These in turn have continued to attract public resources with the specific purpose of stabilising employment, as well as maintaining some of the benefits that these firms have provided in lieu of local government (Commander and Jackman, 1997). Put simply, the inherited employment distribution has materially affected the allocation of resources. Firms with concentrated employment have been able to lobby various levels of government due to the latters' sensitivity to raising open unemployment rates, particularly given large spatial mismatch between job vacancies and workers. ${ }^{3}$ This trend has been associated with the related growth in the size of the state

\footnotetext{
${ }^{2}$ Institute for Social Policy, cited by Bloomberg, 27 May, 2010.

${ }^{3}$ We will be able to look at this in more empirical detail in a later version of the paper using newly available RosStat data that reports subsidies by region and sector for recent years. An instance of this sensitivity is Pikalyovo, a town of around 23,000 inhabitants with two large cement plants where a strike in 2009 led to a visit by the Prime Minister and a promise of investment.
} 
and, in particular, by the growth in government consumption; phenomena driven in much of the last decade by the explicit aim of putting the public sector at the heart of the economy.

This paper looks at whether performance of one-company town enterprises in Russia is consistent with this hypothesis. Certainly, the predicament of one-company towns has often been in the media spot light. However, this could be because the situation of these towns epitomizes the problems of the Russian industry in general and these enterprises are in fact no different from firms elsewhere in the economy. However, our empirical comparison of production functions of enterprises reveals that one-company town enterprises tend to be characterised by significantly lower marginal products of labour and significantly higher marginal products of capital, suggesting substantial labour hoarding. These effects manifest themselves not only in cross-section but also in a panel setting controlling for enterprise fixed effects, suggesting that productivity differentials have been widening. In addition, there is also evidence that overall productivity is substantially lower in one-company-town firms. Finally, the latter are also found to be more indebted, and hence more financially vulnerable, than comparable enterprises located elsewhere, although the economic magnitude of differentials in indebtedness was not as high as that of differentials in the marginal products of labour and capital.

Taken together, these findings are consistent with the hypothesis that natural resource dependence and employment concentration reinforce one another. Commodity revenues make it possible to sustain less efficient enterprises in areas with concentrated employment. In turn, this impedes restructuring in the manufacturing sector and improvements in competitiveness, further locking in dependence on commodity revenues.

The rest of the paper is structured as follows. Section II discusses the implications of a resource boom for allocation of resources and the interaction between resourcedependence and inherited employment concentration structures that may reinforce each other. Section III provides an empirical analysis of enterprise performance in onecompany towns in Russia. A conclusion follows. 


\section{Resource Allocation and One-Company Towns}

\subsection{Resource allocation with a booming sector}

Chart 1 plots the evolution of the oil price ${ }^{4}$ and the real exchange rate for Russia since the mid-1990s. Oil prices have oscillated sharply_from a low of under $\$ 9$ per barrel of Urals in late 1998 to a peak of $\$ 138$ in mid-2008, before falling to a trough of $\$ 35$ per barrel in the same year. By 2010 , prices had rebounded to a range of $\$ 75-85$ per barrel. The chart also shows that since the early 2000 s there has been a very strong appreciation of the exchange rate that was inflected only to a very limited extent at the height of the crisis in 2008-09. Clearly, Russia has been characterised by a booming natural resource sector that has affected relative prices.

\section{Chart 1. Russia: Petroleum prices and real effective exchange rate (REER)}

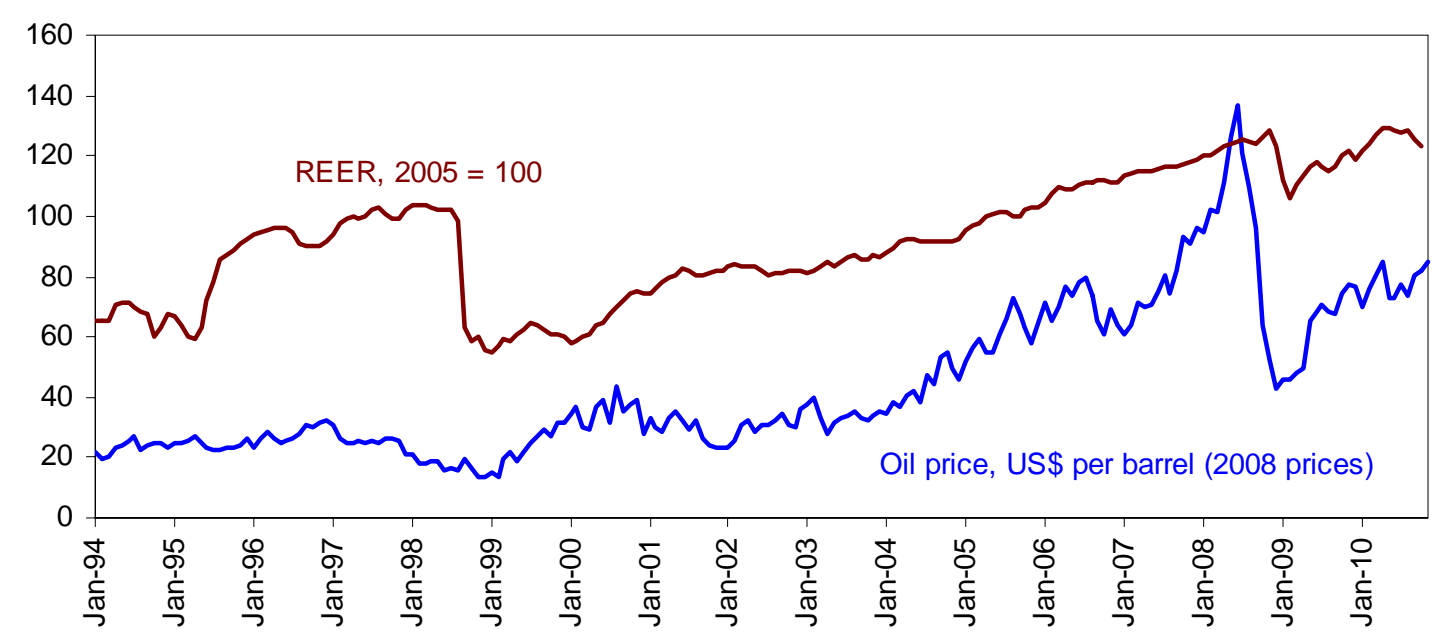

Sources: IMF International Financial Statistics, World Development Indicators and authors' calculations. Oil price is expressed in real terms (2008 prices) using US CPI.

In a general equilibrium setting with non-traded and traded goods, the price of the former will be determined endogenously through domestic supply and demand and the latter be determined exogenously, with equilibrium occurring through adjustment of the price of the non-traded good relative to the traded good, the inverse being the real exchange rate (Salter, 1959; Corden, 1984). A booming natural resource price can induce resource allocation effects as excess demand for non-traded goods leads to real exchange rate

\footnotetext{
${ }^{4}$ Gas prices have tended to follow oil quite closely over most of this period.
} 
appreciation. In addition, spending on non-tradables can raise their relative price. Both channels can affect the composition of output by raising the share of non-traded output in total output. However, any such shifting of resources into non-tradables may lower long run-growth on account of differences in productivity (Van Wijnbergen, 1984; Sachs and Warner, 2001). In short, an increase in the relative price of natural resources, as well as the fact that a part of the revenues from the booming sector will be directly spent on nontraded goods, can affect the dynamic structure of production. These effects could occur in the absence of any political economy considerations. However, as the bulk of revenues from the booming sector in Russia has accrued to government, given its (increasing) ownership and control of the natural resource sectors, political economy considerations are also likely to have been important.

Decomposing spending across tradables and non-tradables is always difficult, not least given data organisation and limitations. In Russia, this is accentuated due to the gap between notional and actual tradability; a legacy of the Soviet past. ${ }^{5}$ Nevertheless, there are several indicators that we can use. Chart 2 gives the evolution of government size using two measures, the national and fiscal accounts. Government size according to the more inclusive fiscal measure increased sharply from around 27\% of GDP in 2000 to $40 \%$ by 2009 while simultaneously accounting for around quarter of aggregate consumption. The growing wedge between the fiscal and national accounts estimates of the size of government reflects the rising importance of transfers recorded both as budget expenditure and private consumption.

\footnotetext{
${ }^{5}$ Specificity in clients and suppliers also contributed to the scale of output contraction that occurred following the demise of the Soviet Union. See Blanchard and Kremer (1997) and Ickes (2008).
} 


\section{Chart 2. Russia: Government expenditure (in per cent of GDP)}

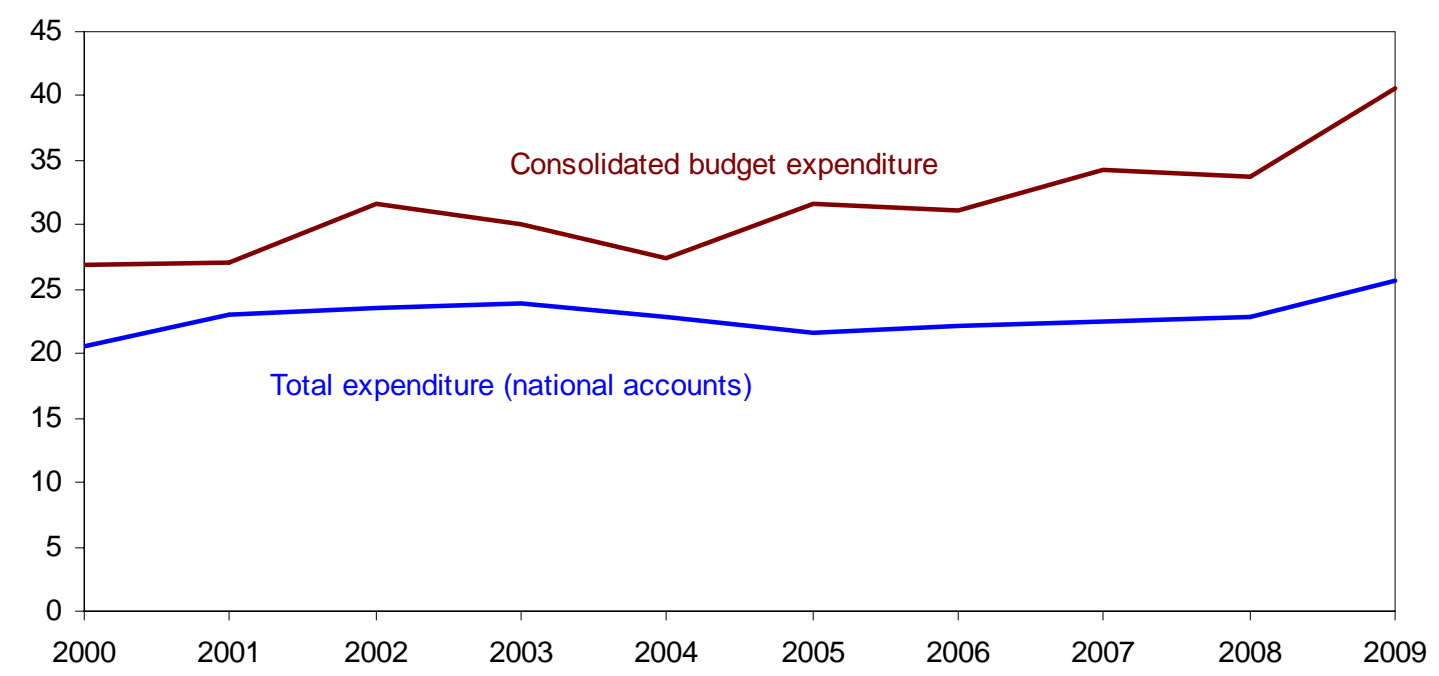

Sources: Ministry of Finance, Rosstat and authors' calculations.

\subsection{Political economy}

Part of the increase in government size can be attributed to the expansion of public employment; government employment at federal, regional and municipal levels grew by over 35\% between 1998-2000 and 2007-09. Chart 3 amplifies the point regarding the importance of public sector employment. Although the share of state and mixed ownership firms that were legal entities in total firms was around $11 \%$, employment in state and mixed firms was almost $40 \%$ in $2007 .{ }^{6}$ A sectoral breakdown would show some preponderance of state ownership in energy and natural resource sectors but also a significant presence in manufacturing and chemicals, among other sectors. Given that government and social services, health and education accounted for around $25 \%$ of total employment at this time, it is evident that the public sector has remained large. In short, resource allocation effects towards non-tradables seem to have been significant.

\footnotetext{
${ }^{6}$ Calculated as firms and organisations including commercial firms, non-commercial organisations and state institutions registered as legal entities, see Sprenger (2008).
} 
Chart 3. Russia: employment share by ownership type (in per cent)

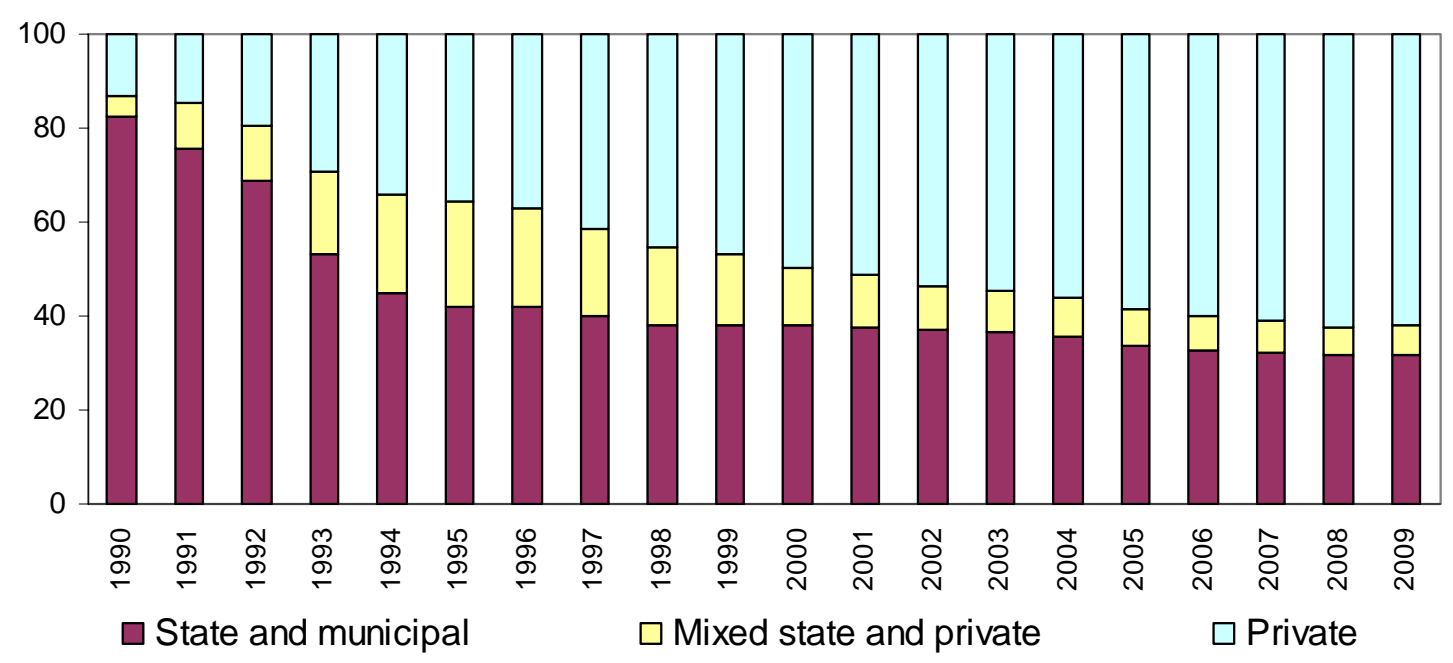

Sources: RosStat and authors' calculations.

Further, employment-motivated spending has been wider. Although explicit subsidies to the entire firm sector have remained small - in the range of 2-5 percent of GDP - this does not capture the full scale and scope of public transfers. The fiscal stimulus package of 2009-2010 had a combination of social spending and support to large firms that accounted for the largest share of the package, amounting to over 3\% of GDP. Declared spending on one-company towns alone in 2010 has been initially put at around $\$ 900$ million. ${ }^{7}$ In addition, in 2009 the government had set up a working group on onecompany towns whereby one-company towns can submit redevelopment programmes and applications for federal co-financing of various investment projects ranging from infrastructure to capital stock modernisation. By end-2010 around 50 comprehensive investment plans had been agreed. All of this suggests that the firm sector and, perhaps particularly, those with concentrated employment have received significant support from government or government controlled institutions.

The impact of high natural resource prices on an economic structure characterised already by low productivity, as well as the persistence of non-market based criteria for resource allocation, is also likely to have political economy dimensions. At its most simplistic, the median voter over time may have increasingly come to resemble a public sector worker.

${ }^{7}$ Speech of the Russian Prime Minister, May 20, 2010 
Yet the classic median voter model does poorly in linking median preferences to policy outcomes and, in the Russian instance, would additionally have to be qualified by the institutional parameters that have surely affected how preferences have been aggregated or indeed have mattered as pluralistic electoral behaviour appears to have been diminished over the reference period. ${ }^{8}$ Yet even though this point seems relevant, the government - federal and sub-national — has clearly remained very sensitive to economic performance (as indicated by the size and configuration of the stimulus programme of 2009-10) and to employment (as indicated by the presence and size of the one-company town programmes). This has influenced the direction and composition of public spending, as commodity rents have been realised. Economic policy and public spending have aimed to raise general living standards through growth ${ }^{9}$ and, at the same time, achieve some redistribution in order to limit unemployment and social unrest. ${ }^{10}$ The latter risk, as already mentioned, has been accentuated by the inheritance of concentrated employment and labour market inefficiencies, notably spatial mismatch.

We argue that the way in which the resource rents have been allocated in Russia has been affected by the inherited configuration of output and employment as well as by the motivation of politicians. Incumbent politicians can acquire an incumbency advantage by using a permanent increase in natural resource rents to 'buy' support through generating employment in the public sector. ${ }^{11}$ But how politicians allocate those resources may also lead to severe mis-allocation both on account of the scale of support buying or through the way in which it is channelled. In the Russian case, the latter seems particularly relevant, not least because public employment is generally inefficient. Further, the adverse effects of resource rent allocations have also been found to be larger where

\footnotetext{
${ }^{8}$ For example, the Heritage or Polity IV political indicators both describe a decline in democratic status.

${ }^{9}$ See, for example, the declared objectives of government economic policy in the immediate aftermath of the 2008 crisis.

10 This relates to the wider literature as to whether natural resources tends to be associated with authoritarian political behaviour or whether dominance of natural resources is more a reflection of political authoritarianism. See, inter alia, Acemoglu, Robinson and Verdier (2006).

${ }^{11}$ For a model that links politics, natural resources and institutions, see Robinson, Torvik and Verdier (2006). The incumbency bias arises because the incumbent can credibly determine employment in advance.
} 
political and other institutions are weak and limit transparency ${ }^{12}$. Institutional integrity and capacity in Russia, under most measures, has been low and often declining in the recent past.

In this framework, the next sections offer an empirical test of whether enterprises in onecompany towns have been less efficient, suffered from relative resource misallocations and have been financially more vulnerable (in terms of their levels of indebtedness) compared with enterprises in more diversified localities. We find support for these hypotheses. It is preceded by a short overview of economic literature on one-company towns.

\subsection{One-company towns: an overview}

Although one-company towns are often associated with centrally planned economies, they were in fact common elsewhere. One-company towns had grown up in the USA towards the end of the $19^{\text {th }}$ century, particularly in the industrial areas of the Mid-West ${ }^{13}$, and at their peak were over 2,500 in number, accounting for up to $3 \%$ of the US population. In the UK, the Cadbury company town of Bourneville and Lord Lever's Port Sunlight were the best known examples. They reflected a paternalistic motivation by their employers towards their workers (Green, 2010; Solecki, 1996). But other one-company towns, particularly in the mining industry, were characterized by less benign conditions, being driven primarily by geographic considerations (Fishback and Lauszus, 1989, for US; Gibson (1990) for Australia).

One-company towns became particularly widespread in the Soviet Union. This reflected a combination of size - the vast land mass - relatively low population density, and significant deposits of various natural resources, often located in areas with very inhospitable climate (e.g., Norilsk). In part, it also reflected the preference of central planners for scale economies and low input (energy) prices. Finally, a significant number of large industrial enterprises were moved further east from their historical locations

\footnotetext{
${ }^{12}$ See Mehlum, Moene and Torvik (2006).

${ }^{13}$ Pullman, Ohio, built for the 6,000 employees of George Pullman's railway company, and McDonald, Ohio, created by Carnegie Steel Company are prominent examples. See Buder (1967) for an overview.
} 
during the Second World War. Many of them remained in their new locations locations chosen precisely for reasons of poor accessibility.

The economic literature on one-company town enterprises is relatively modest. Rama and Scott (1999) have looked at incomes in one-company towns in Kazakhstan, where monotowns were also common, using data from the 1996 living standards survey and found that labour earnings in a town decreases by approximately 1.5 per cent when the share of its population working for the anchor company decreased by 1 per cent. This could be interpreted as evidence of leverage of one-company enterprises during the early years of transition. Commander and Jackman (1997) looked at the incidence of non-monetary compensation in transition firms, including one company and one industry towns, and showed how the dependence of local public services on the viability of a firm or industry was a serious structural defect in the system of local government finance.

\section{Empirical Analysis}

\subsection{Data}

To identify enterprises in one-company towns and assess their relative performance the analysis below uses the Orbis database of Russian enterprises collected by Bureau van Dijk over the period 2003-08. The database provides annual information on majority of Russian firms covering basic balance sheet aggregates, total employment, industry affiliation, and enterprise location. The panel is unbalanced and coverage generally improves over time. Table 1 summarizes the basic descriptive statistics for selected variables for companies employing more than 25 employees. The table is based on data for 2007. In addition - and for comparison purposes - the lower part of the table includes a summary for some of the variables used in the analysis for the monotown companies. 
Table 1. Descriptive statistics for selected variables

\begin{tabular}{|c|c|c|c|c|c|c|}
\hline Variable & Mean & St. dev. & Median & Min & Max & $k$ var \\
\hline \multicolumn{7}{|c|}{ Overall } \\
\hline \multicolumn{7}{|c|}{ Production variables (in thousands of US dollars, unless otherwise indicated) } \\
\hline Operating revenue (turnov€ & 15,100 & 143,300 & 2,109 & 1 & $6,094,733$ & 949.0 \\
\hline Employment (persons) & 200 & 793 & 59 & 25 & 31,441 & 395.8 \\
\hline Total assets & 12,597 & 129,980 & 1,225 & 2 & $4,986,583$ & $1,031.9$ \\
\hline Fixed assets & 6,141 & 76,789 & 244 & 1 & $2,855,421$ & $1,250.3$ \\
\hline Total assets per employee & 44.9 & 333.6 & 16.7 & 0.0 & $25,151.8$ & 742.6 \\
\hline Fixed assets per employee & 18.7 & 221.8 & 3.4 & 0.0 & $16,896.0$ & $1,185.3$ \\
\hline Revenue per employee & 35.5 & 234.9 & 20.5 & 0.0 & $18,949.1$ & 661.0 \\
\hline \multicolumn{7}{|c|}{ Financial structure variables (in per cent, unless otherwise indicated) } \\
\hline Tangibility ratio & 29.2 & 22.8 & 25.4 & 0.0 & 99.7 & 78.1 \\
\hline Profitability ratio & 12.3 & 18.5 & 8.9 & -99.7 & 99.9 & 150.4 \\
\hline Long-term debt-to-assets r. & 6.9 & 16.3 & 0.0 & 0.1 & 99.6 & 236.2 \\
\hline Debt-to-assets ratio & 18.6 & 23.0 & 8.6 & 0.0 & 99.8 & 123.7 \\
\hline
\end{tabular}

One-company town enterprises (using the 5 per cent cut-off)

Production variables (in thousands of US dollars, unless otherwise indicated)

$\begin{array}{lcccccc}\text { Operating revenue (turnove } & 129,412 & 492,275 & 13,001 & 3 & 4,098,520 & 380.4 \\ \text { Employment (persons) } & 1,564 & 3,446 & 466 & 52 & 31,441 & 220.3 \\ \text { Total assets } & 134,369 & 526,353 & 10,239 & 26 & 3,466,946 & 391.7 \\ \text { Fixed assets } & 79,949 & 343,551 & 3,815 & 1 & 2,799,211 & 429.7 \\ \text { Total assets per employee } & 50.5 & 132.5 & 22.4 & 0.1 & 1,250.3 & 262.3 \\ \text { Fixed assets per employee } & 27.5 & 98.4 & 7.4 & 0.0 & 1,009.5 & 357.4 \\ \text { Revenue per employee } & 30.5 & 61.4 & 18.6 & 0.0 & 608.7 & 201.3\end{array}$

Financial structure variables (in per cent, unless otherwise indicated)

$\begin{array}{lcccccc}\text { Tangibility ratio } & 40.2 & 20.5 & 39.1 & 0.1 & 95.9 & 51.0 \\ \text { Profitability ratio } & 11.8 & 15.1 & 9.0 & -42.9 & 72.1 & 128.0 \\ \text { Long-term debt-to-assets r. } & 11.1 & 19.3 & 0.0 & 0.0 & 93.3 & 173.9 \\ \text { Debt-to-assets ratio } & 27.4 & 25.6 & 19.7 & 0.0 & 99.8 & 93.4\end{array}$

Sources: Bureau Van Dijk, authors' calculations.

Notes: Based on year 2007; 7,080 observations for production variables (of which 177 in one-company towns); and 17,050 observations for financial structure variables (of which 561 in one-company towns). $\mathrm{K}$ var is coefficient of variation (in per cent).

The judgement about what constitutes a one-company town - i.e. a town dominated by one enterprise - is inevitably subjective, as almost no town has strictly one firm operating in it. In this light and in order to identify enterprises that account for a large share of employment in their respective locations, the population data were matched for each town using the 2002 population Census results published by the Office of Statistics 
(RosStat). ${ }^{14}$ Thus, each mining and manufacturing enterprise can be characterized in terms of the share of the local population it employs. In the absence of detailed data on demographics and employment structure in each town it is necessary to make a judgement on what share of population employed by an enterprise will qualify it as a monotown enterprise. Back-of-envelope estimates, as well as some prominent examples of one-company towns, suggest a threshold of around 5 per cent. On average, the employment-to-population ratio in Russia is around 48 per cent and has been broadly stable over years and across regions. Most people are employed in services, manufacturing accounts for 16.5 per cent of total employment, and mining for additional 1.5 per cent. Thus, on average manufacturing and mining employ around 8.5 per cent of population. Services tend to be concentrated in large and coastal cities, and agriculture in rural areas, implying that manufacturing-oriented one-company towns will have a much higher share of population employed in manufacturing and mining. Nonetheless, services (including government and social services, education, health care, real estate, construction) are still likely to account for around two thirds of employment. Thus an enterprise employing 5 per cent of the population is likely to account for more than a third of employment in core industries (manufacturing and mining) while a manufacturing enterprise employing 10 per cent of the population will almost certainly dominate the economy of the locality and the livelihood of its people.

These thresholds also seem to be consistent with cases of one-company enterprises that have made headlines in Russia since $2008-09$. For example, a 16,000 population city Baikalsk in Irkutsk Region - came to prominence for environmental and social considerations. The livelihood of the majority of population depends on a single enterprise, a paper factory built in the $1960 \mathrm{~s}$, which is a major polluter situated on the banks of the world's largest fresh water lake. Before the suspension of activity in 2008 the factory employed around 2,300 people or 14 per cent of the population. After numerous protests, the government granted the factory exemption from ecological

\footnotetext{
${ }^{14}$ The Census provides population figures individually for all towns with a population over 3,000 people as well as for smaller towns and villages in less densely populated areas.
} 
standards applied around the Baikal Lake and production has resumed. The town was also included in the mono-town assistance federal programme.

Avtovaz, the giant car maker which employed around 100,000 people and had to be bailed out by the federal government when demand for passenger cars dropped sharply at the height of the crisis, accounts for a similar share of the population in Togliatti, a $700,000+$ city in the Samara Region. Although Togliatti is much larger than Baikalsk and is not a single industry city in strict sense - it is home to Russia's biggest ammonia manufacturer and a major dairy factory - Avtovaz is absolutely central to the local economy.

Pikalyovo, a 23,000 population town in Leningrad Region became widely known in June 2009 when employees of three local enterprises blocked the St. Petersburg-Vologda highway demanding that wage arrears be cleared and job security ensured ${ }^{15}$. The enterprises are closely interlinked, having been part of one cement production chain, however, the cement factory alone, which employed around 800 people, falls short of the 5 per cent of population threshold. Nonetheless, together, the related enterprises employ over 10 per cent of the population and effectively determine the fortunes of this oneindustry town.

In similar vein, the World Bank (2010) highlights the case of Dalnegorsk, a remote town in the Russian Far East with a population of 40,000 people. The local economy is underpinned by two enterprises, Dalpolimetal, a zinc producer founded in 1897 and employing 2,000 people, and Bor, a boric acid producer founded in 1958 and employing over 3,400 people (both Dalnegorsk firms clear the 5 per cent threshold but neither employs more than 10 per cent of town's population). Both enterprises are in a difficult financial situation, and diversification options for the city are constrained by its very remote location.

The definition of one-company town enterprise as one that employs over 5 per cent of the population seems to accommodate these recent high-profile cases. A stricter 10 per cent

\footnotetext{
${ }^{15}$ A notable piece of political theatre followed in which the Prime Minister on camera berated the owner of the plant, the oligarch, Deripaska. That did not, however, stop the latter's Basic Element being a major recipient of public support in the crisis.
} 
threshold can also be applied. The key limitation of both definitions is the possibility that an enterprise is split vertically along the value added chain into separate independent enterprises and none of the components clear the definition threshold or, conversely, that the accounts of the enterprise are consolidated into a nation-wide industrial group which owns different production facilities. While both consolidation and disaggregation cases can be found in the data, they do not seem to be widespread.

Finally, to avoid a situation where enterprises around the 5 per cent threshold switch their status from year to year, maximum employment over the period 2003-08 is used to assign the one-company town status.

\subsection{One-company town enterprises in the data}

Overall, the list of one-company enterprises (using the 5 per cent cut-off) comprises 868 firms with wide dispersion across regions and industries, of which 392 companies also clear the 10 per cent threshold. This list is not comprehensive as it is subject to disaggregation and consolidation caveats, and a number of relevant firms may not feature in the Orbis database or may not have their employment or industry recorded correctly, as Orbis covers around 84 per cent of manufacturing and mining employment reported and assigned to individual industries in RosStat yearbooks. Nonetheless, it is likely to provide a close first approximation of reality.

Table 2 shows that one-company town enterprises account for over 17 per cent of overall employment in mining and manufacturing. They are particularly prevalent in the industrial core of Russia - the Urals Federal District - where they employ every third manufacturing and mining worker. In terms of industry breakdown (Table 3), mining comes first with roughly half of employment concentrated in one-company town enterprises. This is intuitive, as mining towns tend to grow for specific purpose of minerals extraction and remain undiversified economic localities in often remote areas. One-company town enterprises also account for 31 per cent of employment in vehicle manufacturing; 23 per cent in metals; 17 per cent in petrochemicals and 15 per cent in wood processing and paper manufacturing. Coincidentally, the examples mentioned above cover all these industries. But even in light industry, a non-negligible share of 
employment is accounted for by one-company towns (up to 10 per cent in the textile sector).

Table 2. Russian manufacturing and mining employment by region

(Number of employees)

\begin{tabular}{|c|c|c|c|c|}
\hline $\begin{array}{l}\text { Federal } \\
\text { district }\end{array}$ & $\begin{array}{l}\text { One-company } \\
\text { towns with } 10 \\
\text { percent cut-off }\end{array}$ & $\begin{array}{c}\text { One-company } \\
\text { towns with } 5 \\
\text { percent cut-off }\end{array}$ & Dataset total & $\begin{array}{l}\text { RosStat total } \\
\text { (2007) }\end{array}$ \\
\hline Urals & 346,563 & 458,987 & $1,076,459$ & $1,260,154$ \\
\hline Volga & 342,359 & 580,781 & $1,948,471$ & $2,622,974$ \\
\hline North West & 121,698 & 143,932 & 898,321 & $1,061,758$ \\
\hline Central & 142,794 & 347,498 & $2,780,811$ & $2,857,005$ \\
\hline Far East & 30,235 & 36,616 & 218,918 & 324,615 \\
\hline Siberia & 73,305 & 109,315 & 852,271 & $1,222,721$ \\
\hline South & 16,576 & 28,217 & 601,995 & 884,242 \\
\hline TOTAL & $1,073,530$ & $1,705,346$ & $8,377,246$ & $10,233,469$ \\
\hline $\begin{array}{l}\text { Federal } \\
\text { district }\end{array}$ & $\begin{array}{c}\text { OCT (5\%) in per } \\
\text { cent of dataset } \\
\text { employment }\end{array}$ & $\begin{array}{c}\text { Dataset in \% of } \\
\text { RosStat } \\
\text { employment }\end{array}$ & $\begin{array}{l}\text { OCT (5\%) in per } \\
\text { cent of RosStat } \\
\text { employment }\end{array}$ & $\begin{array}{c}\text { OCT }(10 \%) \text { in } \\
\text { per cent of } \\
\text { RosStat }\end{array}$ \\
\hline Urals & 42.6 & 85.4 & 36.4 & 27.5 \\
\hline Volga & 29.8 & 74.3 & 22.1 & 13.1 \\
\hline North West & 16.0 & 84.6 & 13.6 & 11.5 \\
\hline Central & 12.5 & 97.3 & 12.2 & 5.0 \\
\hline Far East & 16.7 & 67.4 & 11.3 & 9.3 \\
\hline Siberia & 12.8 & 69.7 & 8.9 & 6.0 \\
\hline South & 4.7 & 68.1 & 3.2 & 1.9 \\
\hline TOTAL & 20.4 & 81.9 & 16.7 & 10.5 \\
\hline
\end{tabular}

Sources: RosStat, Bureau Van Dijk, authors' calculations. Rosstat total 
Table 3. Russian manufacturing and mining employment by industry

(Number of employees)

\begin{tabular}{|c|c|c|c|c|}
\hline Industry & $\begin{array}{l}\text { One-company } \\
\text { towns with } 10 \\
\text { percent cut-off }\end{array}$ & $\begin{array}{c}\text { One-company } \\
\text { towns with } 5 \\
\text { percent cut-off }\end{array}$ & Dataset total & RosStat total \\
\hline Manufacturing & 664,983 & $1,228,399$ & $7,364,325$ & $9,258,943$ \\
\hline Vehicles & 202,179 & 358,075 & 772,839 & $1,147,900$ \\
\hline Metals & 132,882 & 264,028 & $1,105,241$ & $1,153,700$ \\
\hline Petrochemicals & 79,018 & 153,709 & 806,253 & 931,300 \\
\hline Wood and paper & 74,584 & 119,018 & 599,451 & 739,400 \\
\hline Minerals & 50,665 & 81,917 & 511,682 & 675,000 \\
\hline Textile & 34,225 & 47,445 & 301,259 & 509,900 \\
\hline Food & 57,167 & 106,267 & $1,388,482$ & $1,456,500$ \\
\hline Electronics & 14,270 & 36,543 & 851,200 & 905,700 \\
\hline Machinery & 7,936 & 43,276 & 848,098 & $1,108,600$ \\
\hline Other manufacturing & 12,057 & 18,121 & 179,820 & 630,943 \\
\hline Mining & 408,547 & 476,947 & $1,012,921$ & 974,526 \\
\hline Oil and gas & 125,896 & 142,087 & 270,229 & 619,400 \\
\hline Other mining & 282,651 & 334,860 & 742,692 & 355,126 \\
\hline TOTAL & $1,073,530$ & $1,705,346$ & $8,377,246$ & $10,233,469$ \\
\hline Industry & $\begin{array}{c}\text { OCT }(5 \%) \text { in per } \\
\text { cent of dataset } \\
\text { employment }\end{array}$ & $\begin{array}{c}\text { Dataset in \% of } \\
\text { RosStat } \\
\text { employment }\end{array}$ & $\begin{array}{c}\text { OCT (5\%) in per } \\
\text { cent of RosStat } \\
\text { employment }\end{array}$ & $\begin{array}{c}\text { OCT (10\%) in } \\
\text { per cent of } \\
\text { RosStat }\end{array}$ \\
\hline Manufacturing & 16.7 & 79.5 & 13.3 & 7.2 \\
\hline Vehicles & 46.3 & 67.3 & 31.2 & 17.6 \\
\hline Metals & 23.9 & 95.8 & 22.9 & 11.5 \\
\hline Petrochemicals & 19.1 & 86.6 & 16.5 & 8.5 \\
\hline Wood and paper & 19.9 & 81.1 & 16.1 & 10.1 \\
\hline Minerals & 16.0 & 75.8 & 12.1 & 7.5 \\
\hline Textile & 15.7 & 59.1 & 9.3 & 6.7 \\
\hline Food & 7.7 & 95.3 & 7.3 & 3.9 \\
\hline Electronics & 4.3 & 94.0 & 4.0 & 1.6 \\
\hline Machinery & 5.1 & 76.5 & 3.9 & 0.7 \\
\hline Other manufacturing & 10.1 & 28.5 & 2.9 & 1.9 \\
\hline Mining & 47.1 & 103.9 & 48.9 & 41.9 \\
\hline Oil and gas & 52.6 & 43.6 & 22.9 & 20.3 \\
\hline Other mining & 45.1 & 209.1 & 94.3 & 79.6 \\
\hline TOTAL & 20.4 & 81.9 & 16.7 & 10.5 \\
\hline
\end{tabular}

Sources: RosStat, Bureau Van Dijk, authors' calculations. Rosstat total is based on 2007 data.

\subsection{Empirical analysis: Enterprise performance}

To assess whether performance of one-company town enterprises is systematically different from enterprises elsewhere, simple production functions can be considered relating total output to capital stock, labour, and industry and location characteristics. Consider the following specification: 


$$
y_{i t}=\alpha_{1 i}+\beta_{1} k_{i t}+\gamma_{1} l_{i t}+\delta_{t}+\varepsilon_{i t}
$$

where $y$ is logarithm of total turnover (the best available proxy for total sales), $k$ is logarithm of capital stock (fixed assets), $l$ is logarithm of the number of employees (in full-time equivalents), $\delta$ are fixed year effects, subscript $i$ denotes enterprise and subscript $t$ denotes year. All sales and balance sheet variables are expressed in US dollars in constant prices using GDP deflators adjusted for exchange rate fluctuations.

In fixed effects regressions, which control for time-invariant characteristics of enterprises, the status of one-company town enterprises will be part of the fixed effect and cannot be identified separately. However, differences in marginal products of labour and capital (slope coefficients of $k_{i t}$ and $l_{i t}$ ) between one-company town enterprises and other firms can be identified using the following augmented specification:

$$
y_{i t}=\alpha_{2 i}+\beta_{2} k_{i t}+\beta_{3} k_{i t}^{*} D_{i}+\gamma_{2} l_{i t}+\gamma_{3} l_{i t} * D_{i}+\delta_{t}+\varepsilon_{i t}
$$

where $D_{i}$ is a dummy variable for one-company town enterprises using a 5 per cent (or alternative) threshold. Coefficient $\beta_{3}$ shows additional marginal product of capital in onecompany towns relative to enterprises elsewhere, while coefficient $\gamma_{3}$ shows difference in labour productivity between one-company town enterprises and other firms.

Table 4 shows results of fixed effects estimation for all manufacturing (and mining) firms in the sample with 25 employees or more. Column A reports results for a basic production function of the type (R1), in column B interaction terms between capital and one-company town enterprise and labour and one-company town enterprise are added. Further columns report results of several robustness checks. In Column $\mathrm{C}$ mining companies are included alongside manufacturing companies, and in Column D total assets substitute for fixed assets. The key results remain unaffected.

There are a few empirical regularities that emerge from the fixed effects analysis. Most importantly, the coefficients on the interaction term between labour and one-company town dummy is negative and significant, while the interaction term between proxies for capital and the one-company town dummy is positive and significant. These results are indicative of labour hoarding in one-company towns and/or underinvestment in capital stock and technological modernisation. As a robustness check, we include a similar table 
(Annex Table A1) which uses a one-company town dummy set at a higher threshold (10 percent). The results with respect to the coefficients of labour and capital remain unaffected, however the interaction terms mostly lose their significance (only the interaction term between employment and the one-company town in Column $\mathrm{C}$ is significant, albeit at a 10 percent level of significance).

The coefficient of the interaction term between employment and one-company town dummy is negative and significant, suggesting that a 10 percent increase in employment in one-company town companies is associated with an approximately 1.5 percentage points lower increase in output than at other comparable enterprises. As mentioned above, the sign of the interaction term is also indicative of possible labour hoarding in these types of companies. On the other hand, an increase in capital in one-company towns is associated with a 1.5 or 3 percent higher increase in output compared with peers elsewhere (depending whether fixed or total assets are used as proxies for capital). This could be an indication of possible underinvestment in capital stock and technological modernization. ${ }^{16}$

\footnotetext{
${ }^{16}$ To check if the results for one-company town enterprises merely reflect the fact that one-company town enterprises tend to be large, robustness checks also included specifications with dummy variables for other large enterprises (those employing more than 500 people or more than 1,000 people) and the respective interaction terms with measures of labour and capital. The effects specific to one-company towns persist. In addition, the estimation provides some evidence of labour hoarding and lower marginal product of labour in large companies. The results are available upon request.
} 
Table 4. Production functions: Fixed effects estimation

Dependent variable: Operating revenue, log

\begin{tabular}{|c|c|c|c|c|}
\hline Fixed effects & A & B & C & D \\
\hline Employment, log & $.878^{\star \star \star}(.012)$ & 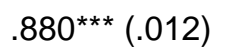 & $.887^{\star \star \star}(.012)$ & $.764^{\star \star \star}(.011)$ \\
\hline Fixed assets, log & $.197 * * *(.007)$ & $.195^{\star \star \star}(.007)$ & $.198 * \star \star(.006)$ & \\
\hline Total assets, log & & & & $.411 * * *(.009)$ \\
\hline Log employment * OCT & & $-.143^{\star}(.082)$ & $-.169 * *(.070)$ & $-.117(.084)$ \\
\hline Log fixed assets * OCT & & $.169 *(.094)$ & $.150 *(.079)$ & \\
\hline Log total assets * OCT & & & & $.330 * * *(.124)$ \\
\hline Constant & $2.247^{\star \star \star}(.055)$ & $2.238^{\star * \star}(.055)$ & $2.202^{\star \star \star}(.054)$ & $1.014^{\star * \star}(.058)$ \\
\hline Year fixed effects & Yes & Yes & Yes & Yes \\
\hline Number of observations & 56,332 & 56,332 & 61,196 & 63,027 \\
\hline Number of groups & 19,179 & 19,179 & 20,981 & 20,950 \\
\hline $\mathrm{R}^{2}$ & 0.61 & 0.61 & 0.62 & 0.66 \\
\hline
\end{tabular}

Notes: Estimated by fixed effects, robust standard errors in parentheses. All variables are expressed in real terms using GDP deflators. Sample includes manufacturing firms employing 25 people or more, 2003-08. OCT is one-company town enterprise dummy (using 5 per cent cut-off). ${ }^{* \star}$ indicates significance at 1 the per cent level, ${ }^{*}$ at the 5 per cent level, and * at the 10 per cent level.

Fixed effects estimation may understate productivity problems in one-company towns as the time-invariant (systematic) component of lower output of these enterprises, if any, will be subsumed by enterprise fixed effects. A complementary approach would be to focus on cross-enterprise dimensions of the dataset and analyse the between effect estimates of productivity. Between effects estimation exploits differences in average output over a certain period of time (2006-08 in this case) and differences in time averages of the explanatory variables. ${ }^{17}$ Specification (R3) is a cross-sectional adaptation of specification (R2): augmented with industry dummies (at two-digit level), federal district dummies, as well as a dummy variable for one-company town enterprises (denoted $X_{i}$ ).

$$
y_{i t}=\alpha_{3}+\beta_{4} k_{i t}+\beta_{5} k_{i t} * D_{i}+\gamma_{4} l_{i t}+\gamma_{5} l_{i t} D_{i}+\sigma D_{i}+\lambda X_{i}+\eta_{i t}
$$

Table 5 summarizes the results of the between effects estimation. Column A reports coefficients of a basic production function, which is augmented with one-company

\footnotetext{
${ }^{17}$ For cross-sectional analysis the sample was restricted to the sub-period of $2006-08$ as data availability for the earlier period (2003-05) is relatively poor. The results generally hold if the entire period of 2003-08 is considered.
} 
enterprise dummy and the corresponding interaction terms in Column B. As expected, the implied differences in productivity between one-company town enterprises and other firms become larger. Firstly, the one-company town dummy is negative and significant, and its magnitude is far higher than those of the industry or regional dummy. In quantitative terms, it suggests that the output of a one-company town enterprise is up to 70 per cent lower compared with its peers, other things being equal. ${ }^{18}$ Coefficients on the interaction terms suggest that the marginal product of labour is lower and marginal product of capital is higher in one-company town enterprises and these effects are statistically and economically significant. These results are indicative of labour hoarding in one-company towns and/or underinvestment in capital stock and technological modernisation. As a robustness check we include an annex table (Annex Table A2) which uses a higher threshold one-company town dummy (10 percent). The one-company town dummy is still negative and significant, with comparable magnitude to the one at the five percent threshold. In addition, the coefficients on the interaction terms are broadly the same in terms of sign and magnitude (however, the interaction term between the onecompany town dummy and employment loses its significance across all models).

The coefficient of the interaction term suggests that an increase of employment by 10 percent in the one-company town companies is associated with an average of 3 percentage points lower increase in output compared with other enterprises. Similarly, an increase in capital in one-company towns is associated with a 3 percentage points higher increase in output. Just as in the fixed effects estimations above, the results suggest possible labour hoarding and underinvestment in capital taking place in one-company towns.

\footnotetext{
${ }^{18}$ Logarithmic transformation implies that the coefficient $\sigma$ of the one-company town dummy variable corresponds to the term $\mathrm{e}^{\sigma}$ in multiplicative production function of Cobb-Douglas type. For instance, the coefficient of -1.2 corresponds to a multiplicative term of 0.3 .
} 
Table 5. Production functions: Cross-section analysis

Dependent variable: Operating revenue, log

\begin{tabular}{lccccc}
\hline \multicolumn{1}{c}{ Between effects } & A & B & C & D & E \\
\hline Employment, log & 0.891 & 0.904 & 0.916 & 0.917 & 0.608 \\
& $(.010)^{\star \star \star}$ & $(.011)^{\star \star \star}$ & $(.010)^{\star \star \star}$ & $(.010)^{\star \star \star}$ & $(.010)^{\star \star \star}$ \\
Fixed assets, log & 0.121 & 0.119 & 0.109 & 0.118 & \\
& $(.005)^{\star \star \star}$ & $(.005)^{\star \star \star}$ & $(.004)^{\star \star \star}$ & $(.004)^{\star \star \star}$ & \\
Total assets, log & & & & & 0.414 \\
& & & & & $(.006)^{\star \star \star}$ \\
Log employment * OCT & & -0.280 & -0.251 & -0.231 & -0.209 \\
& & $(.084)^{\star \star \star}$ & $(.085)^{\star \star \star}$ & $(.067)^{\star \star \star}$ & $(.085)^{\star \star}$ \\
Log fixed Assets * OCT & & 0.337 & 0.350 & 0.280 & \\
& & $(.052)^{\star \star \star}$ & $(.053)^{\star \star \star}$ & $(.041)^{\star \star \star}$ & \\
Log total Assets * OCT & & & & & 0.329 \\
OCT & & & & & $(.063)^{\star \star \star}$ \\
Constant & & $(.4 .199$ & -1.508 & -1.074 & -2.005 \\
& & $(.426)^{\star \star \star *}$ & $(.351)^{\star \star \star}$ & $(.434)^{\star \star \star}$ \\
Regional dummies & Yes & Yes & No & Yes & Yes \\
Industry dummies & Yes & Yes & No & Yes & Yes \\
Number of observations & 28,511 & 28,511 & 28,511 & 30,954 & 31,631 \\
Number of groups & 13,385 & 13,385 & 13,385 & 14,602 & 14,751 \\
$\mathrm{R}^{2}$ & 0.56 & 0.56 & 0.56 & 0.57 & 0.64 \\
\hline
\end{tabular}

Notes: Estimated by the between estimator, robust standard errors in parentheses. All variables are expressed in real terms using GDP deflators. Sample includes manufacturing firms employing 25 people or more, 2006-08. OCT is one-company town enterprise dummy (using 5 per cent cut-off). *** indicates significance at 1 the per cent level, ${ }^{\star *}$ at the 5 per cent level, and * at the 10 per cent level.

Columns $\mathrm{C}, \mathrm{D}$, and $\mathrm{E}$ report the results of several robustness checks. In Column $\mathrm{C}$ industry and regional dummies are dropped; in Column D mining firms are included alongside manufacturing enterprises; and in Column E total assets substitute for fixed assets. $^{19}$

\footnotetext{
${ }^{19}$ When dummy variables for other large companies are included separately or jointly with one-company town dummies, the differentials in marginal products of labour and capital for one-company town enterprises prove to be much stronger than for large companies overall.
} 


\subsection{Empirical analysis: Indebtedness and financial vulnerability}

The analysis above suggests that the problems of one-company town enterprises are not merely problems of an average Russian enterprise put in the spotlight because of its significance in the local economy. They appear to be compounded by even greater labour hoarding, lack of restructuring, and hence lower productivity. A related question is whether these enterprises are also more indebted and more financially vulnerable than their counterparts in more diversified local economies.

Following Rajan and Zingales (1995) the basic specification (R4) explaining indebtedness of a firm (ratio of debt to total assets, $D d$ ) includes a measure of tangibility (the ratio of fixed assets to total assets, Tng), firm size (in terms of employment or turnover, Size), profitability (the return on assets, $\operatorname{Prf}$ ) and industry affiliation and region $(X)$ :

$$
D d_{i t}=\alpha_{i t}+\beta \operatorname{Tng}_{i t}+\gamma \operatorname{Size}_{i t}+\mu P r f_{i t}+\sigma D_{i}+\lambda X_{i}+v_{i t}
$$

Tangibility is expected to be positively associated with debt-to-assets ratio as more capital-intensive firms can offer better collateral on the one hand and tend to require more external financing for investment projects on the other. Size is also expected to have a positive effect, while the effect of profitability is ambiguous: profitable firms may have more opportunities to finance investments out of cash flow but they may also seek to expand more aggressively. In addition, specification (R4) includes a dummy variable for one-company town enterprises $(D)$. As the analysis focuses on cross-firm differences in average indebtedness, the model is estimated using the between panel estimator effectively employing average indicators for each firm for the period 2006-08.

Table 6 summarizes the results for censured Tobit regressions when the long-term debt to assets ratio is used as a measure of financial leverage. Column A reports the basic Rajan and Zingales (1995) specification augmented with the one company town dummy. Consistent with their analysis, the coefficients on tangibility and size are positive and significant, while the coefficient of profitability is negative and significant. The magnitude and significance of the one company town coefficient suggests that enterprises in one-company towns have, on average, higher long-term debt-to-assets ratios. In numerical terms the size of the coefficient would imply that the long-term debt to assets 
ratio in the one-company towns is on average about 1.5 percent higher. Columns $\mathrm{B}, \mathrm{C}$, and $\mathrm{D}$ report additional model specifications. In model $\mathrm{B}$, regional and sector dummies are introduced to the main specification, while in model $\mathrm{C}$, the sample includes manufacturing and mining companies. Finally, in column D logarithm of revenue per employee is included as an additional explanatory variable. This does not affect the results.

Table 6. Financial leverage: Long-term debt

Dependent variable: Long-term debt-to-assets ratio

\begin{tabular}{|c|c|c|c|c|}
\hline Tobit estimates & A & B & C & D \\
\hline Tangibility & $.451^{\star \star \star}(.012)$ & $.397^{\star \star \star}(.012)$ & $.407^{\star \star \star}(.012)$ & $.431^{\star \star \star}(.018)$ \\
\hline Employment, log & $.036^{\star \star \star}(.002)$ & 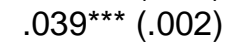 & $.036^{\star \star \star}(.002)$ & 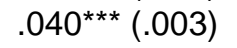 \\
\hline Profitability & $-.079 * * *(.022)$ & $-.071 * * *(.020)$ & $-.084 * * *(.022)$ & $-.064 * * *(.021)$ \\
\hline OCT & $.054 * * *(.013)$ & $.036 * * *(.013)$ & $.021 *(.012)$ & $.066 * *(.026)$ \\
\hline Revenue per employee, log & & & & $.040 * \star \star(.003)$ \\
\hline Constant & $-.434 \star \star \star ~(.010)$ & $-.350 * \star *(.021)$ & $-.413^{\star \star *}(.013)$ & $-.514 * \star *(.032)$ \\
\hline Regional dummies & No & Yes & Yes & Yes \\
\hline Industry dummies & No & Yes & Yes & Yes \\
\hline Number of observations & 22,715 & 22,715 & 24,845 & 12,633 \\
\hline Pseudo $\mathrm{R}^{2}$ & 0.12 & 0.14 & 0.14 & 0.14 \\
\hline
\end{tabular}

Notes: Estimated by the tobit estimator using averages over 2006-08, standard errors in parentheses. Revenue is expressed in real terms using GDP deflator. Tangibility is the ratio of fixed assets to total assets; profitability is EBIT-to-assets ratio. Sample includes manufacturing firms employing 25 people or more, 2006-08. OCT is one-company town enterprise dummy (using 5 per cent cut-off). *** indicates significance at 1 the per cent level, ${ }^{* *}$ at the 5 per cent level, and ${ }^{*}$ at the 10 per cent level.

Table 7 summarizes the results when the financial leverage proxy is broader and uses the ratio of long-term debt and short-term debt to assets as a dependent variable. The models are analogous to the models in Table 6. As in the previous table, the proxies for tangibility and size are positive and significant, while the proxy for profitability is negative and significant. The magnitude of the coefficient on the one-company dummy suggests that the debt-to-assets ratio is about 3 percentage points higher in one-company 
town companies, other things being equal. This coefficient is statistically significant at the 5 per cent level in most specifications. ${ }^{20}$

Table 7. Financial leverage: Long-term and short-term debt

Dependent variable: Long-term debt-to-assets ratio

\begin{tabular}{lcccc}
\hline \multicolumn{1}{c}{ Tobit estimates } & A & B & C & D \\
\hline Tangibility & $.320^{* \star *}(.010)$ & $.235^{\star * *}(.010)$ & $.245^{\star * *}(.010)$ & $.255^{\star * *}(.014)$ \\
Employment, log & $.031^{\star \star *}(.001)$ & $.033^{\star * *}(.001)$ & $.029^{\star * *}(.001)$ & $.034^{\star * *}(.002)$ \\
Profitability & $-.180^{* * *}(.052)$ & $-.161^{* * *}(.047)$ & $-.178^{* * *}(.048)$ & $-.141^{* * *}(.054)$ \\
OCT & $.070^{* * *}(.013)$ & $.047^{* * *}(.012)$ & $.027^{* *}(.011)$ & $.067^{* * *}(.022)$ \\
Revenue per employee, log & & & & $.027^{* * *}(.003)$ \\
Constant & $-.093^{\star * *}(.010)$ & $-.021(.019)$ & $-.063^{* * *}(.011)$ & $-.121^{\star * *}(.025)$ \\
Regional dummies & No & Yes & Yes & Yes \\
Industry dummies & No & Yes & Yes & Yes \\
Number of observations & 22,508 & 22,508 & 24,592 & 12,468 \\
Pseudo $\mathrm{R}^{2}$ & 0.12 & 0.21 & 0.20 & 0.19 \\
\hline
\end{tabular}

Notes: Estimated by the tobit estimator using averages over 2006-08, standard errors in parentheses. Revenue is expressed in real terms using GDP deflator. Tangibility is the ratio of fixed assets to total assets; profitability is EBIT-to-assets ratio. Sample includes manufacturing firms employing 25 people or more, 2006-08. OCT is one-company town enterprise dummy (using 5 per cent cut-off). ${ }^{* *}$ indicates significance at 1 the per cent level, ${ }^{\star \star}$ at the 5 per cent level, and ${ }^{*}$ at the 10 per cent level.

As a robustness check, we also include two equivalent tables which use a higher threshold one-company town dummy (ten percent). Table A3 uses the ratio of long-term debt to assets as a measure of financial leverage, while in Table A4 the dependent variable is the ratio of the sum of long-term debt and short-term debt (loans) to total assets. As in Tables 6 and 7, the magnitude and significance of the main determinants of financial leverage remain unaffected by use of the new dummy variable. Hence, both tangibility and size are positive and significant across all models, while profitability is negative and significant. The size and magnitude of the new dummy variable are comparable to those in Tables 6 and 7, although its significance drops in model $\mathrm{C}$ in Table A4.

\footnotetext{
${ }^{20}$ As before, the exercise was reproduced using dummy variables for large companies. The coefficients for monotown companies retained their sign and statistical significance, while the large company dummy proved to be insignificant.
} 


\section{Conclusion}

Our paper has explored the links between resource dependence, employment concentration and resource allocation. We argue that dependence on commodity rents and high employment concentrations - manifested in the widespread presence of onecompany towns - can interact, locking in a pattern of sub-optimal resource allocation while also impeding enterprise restructuring, modernisation and diversification of the economy. For political economy reasons, resource rents are channelled to localities with high employment concentration, which primarily supports labour hoarding. In turn, this can lead to a further decline of the non-resource sector (already affected by the change in relative prices and the real exchange rate). As such, the boom in natural resources in Russia has been associated with resource rent allocations that respect political objectives, notably of support buying (or perhaps, more accurately, opposition neutralising). With weak institutions, this has likely accentuated adverse efficiency effects.

Empirical support for these conjectures has been marshalled in our paper by identifying one-company towns using a large dataset of Russian enterprises and matching enterprise data with Census population data for the towns in which firms are located. Our analysis has confirmed the significance of one-company towns more than twenty years into transition - they were found to account for 13 to 17 per cent of manufacturing employment country-wide and over a third of manufacturing employment in the Urals Federal District - the industrial core of Russia.

Comparison of production functions of enterprises revealed that one-company town enterprises tend to be characterised by significantly lower marginal products of labour and significantly higher marginal products of capital, suggesting substantial labour hoarding in one-company-town firms. These effects manifest themselves not only in the cross-section but also in a panel setting controlling for enterprise fixed effects, suggesting the widening of productivity differentials. In addition, there is also evidence that overall productivity is substantially lower in one-company-town firms. Finally, the latter also were found to be more indebted, and hence financially vulnerable, than comparable enterprises located elsewhere, although the economic magnitude of differentials in 
indebtedness was not as high as that of differentials in the marginal products of labour and capital

Overall, the analysis suggests that employment concentration, including in its extreme form of one-company towns, presents specific policy challenges. In particular, it appears that distortionary resource allocation has been particularly acute in the case of onecompany towns. Support to loci of concentrated employment, drawing on natural resource rents, may have achieved some form of employment (although not earnings) stability and abatement of social tension but, coupled to the broader re-allocation of resources to public consumption, this has undoubtedly imposed costs. Further, these sorts of transfer policies appear to have been used as substitutes, rather than as complements, to other policies designed to help restructuring and reallocation, such as better policies for entry as well as for retraining and other measures aimed at better labour market performance. While allocations to one-company towns are not the largest component of resource rent allocations, put together with other components, the pattern that can be observed is one that is likely to be antithetical to diversification and accelerated growth; objectives that, at least notionally, have been espoused by the Russian government. 


\section{References}

D. Acemoglu, J. Robinson, and T. Verdier (2004), "The Kleptocracy and Divide-andRule: A Model of Personal Rule", Journal of the European Economic Association 2: 162-92.

O. Blanchard and M. Kremer (1997), "Disorganization," Quarterly Journal of Economics 112, no 4: 1091-1126.

A. Brown, B. Ickes, and R. Ryterman (1994), "The Myth of Monopoly: A New View of Industrial Structure in Russia", World Bank Policy Research Working Paper 1331.

S. Buder (1967), Pullman: An Experiment in Industrial Order and Community Planning, 1880-1930, New York: Oxford University Press.

S. Commander and R. Jackman (1997), "Firms and Government in the Provision of Benefits in Russia", in Martin Rein and Barry L. Friedman, eds., Enterprise and Social Benefits after Communism, Cambridge: Cambridge University Press.

W. Corden (1984), "Booming Sector and Dutch Disease Economics: Survey and Consolidation", Oxford Economic Papers 36: 359-80.

EBRD (2010), Transition Report 2010, London: EBRD.

P. Fishback and D. Lauszus (1989), "The Quality of Services in Company Towns: Sanitation in Coal Towns during the 1920s," Journal of Economic History 49, no 1: 125-44.

K. Gibson (1990), "Company Towns and Class Processes: A study of the Coal Towns of Central Queensland", Environment and Planning D: Society and Space. 9, no 3: 285-308.

H. Green (2010), The Company Town, New York: Basic Books.

S. Guriev, A. Plekhanov, and K. Sonin (2009), "Development Based on Commodity Revenues", EBRD Working Paper 108.

R. Hausmann and B. Klinger (2007), "The Structure of the Product Space and Comparative Advantage", Harvard University CID Working Paper 146.

B. Ickes (2008), "The Output Fall in Transition," in Steven Durlauf and Larry Blume, eds., The New Palgrave Dictionary of Economics, 2nd edition, Palgrave Macmillan.

M. Kuboniwa, S. Tabata, and N. Ustinova (2005), "How Large is the Oil and Gas Sector in Russia? A Research Report", Eurasian Geography and Economics 46, no 1: $68-76$. 
H. Mehlum, K. Moene, and R. Torvik (2006), "Institutions and the Resource Curse," Economic Journal 116, no 508: 1-20.

R. Rajan and L. Zingales (1995), "What Do We Know about Capital Structure? Some Evidence from International Data," Journal of Finance 50, no 5: 1421-60.

M. Rama and K. Scott (1999), "Labor Earnings in One-Company Towns: Theory and Evidence from Kazakhstan”, World Bank Economic Review 13, no.1: 185-209.

J. Robinson, R. Torvik and T. Verdier (2006), "Political Foundations of the Resource Curse", Journal of Development Economics 79: 447-468

J. Sachs and A. Warner (2001) "Natural Resources and Economic Development: The Curse of Natural Resources", European Economic Review 45, no 4-6: 827-38.

W. Salter (1959), "Internal and External Balance: The Role of Price and Expenditure Effects”, Economic Record 35: 226-38.

W. Solecki (1996), "Paternalism, Pollution and Protest in a Company Town", Political Geography 15, no 1: 5-20.

C. Sprenger (2008), "State-Owned Enterprises in Russia", presented at OECD Conference on Corporate Governance, Mimeo.

S. Van Wijnbergen (1984), "The 'Dutch Disease': A Disease after All?" Economic Journal 94, no 373: 41-55.

World Bank (2004), World Bank Russian Economic Report No 7.

World Bank (2010), “The Challenge of Russia's Monotowns", World Bank Russian Economic Report 22: 21-28. 


\section{Annex}

Table A1. Production functions: Fixed effects estimation (10\% threshold)

Dependent variable: Operating revenue, log

\begin{tabular}{|c|c|c|c|c|}
\hline Fixed effects & A & B & C & D \\
\hline Employment, log & $.878^{\star \star \star}(.012)$ & $.879^{\star \star \star}(.012)$ & $.885^{\star \star \star}(.012)$ & $.762^{\star \star \star}(.011)$ \\
\hline Fixed assets, log & $.197^{\star \star \star}(.007)$ & $.196^{\star \star \star}(.007)$ & $.199 * \star \star(.006)$ & \\
\hline Total assets, log & & & & $.413 * * *(.009)$ \\
\hline Log employment * OCT10 & & $-.065(.083)$ & $-.120 *(.066)$ & $-.100(.095)$ \\
\hline Log fixed assets * OCT10 & & $.215(.154)$ & $.179(.120)$ & \\
\hline Log total assets * OCT10 & & & & $.231(.188)$ \\
\hline Constant & $2.247^{\star \star \star}(.055)$ & $2.240 * \star *(.055)$ & $2.205^{\star \star \star}(.053)$ & 1.030 *** $(.057)$ \\
\hline Year dummies & Yes & Yes & Yes & Yes \\
\hline Number of observations & 56,332 & 56,332 & 61,196 & 63,027 \\
\hline Number of groups & 19,179 & 19,179 & 20,981 & 20,950 \\
\hline $\mathrm{R}^{2}$ & 0.61 & 0.61 & 0.61 & 0.68 \\
\hline
\end{tabular}

Notes: Estimated by fixed effects, robust standard errors in parentheses. All variables are expressed in real terms using GDP deflators. Sample includes manufacturing firms employing 25 people or more, 2003-08. OCT10 is one-company town enterprise dummy (using 10 per cent cut-off). ${ }^{* \star *}$ indicates significance at 1 the per cent level, ${ }^{\star *}$ at the 5 per cent level, and * at the 10 per cent level. 
Table A2. Production functions: Cross-section analysis, $10 \%$ threshold

Dependent variable: Operating revenue, log

\begin{tabular}{lccccc}
\hline \multicolumn{1}{c}{ Between estimates } & A & B & C & D & E \\
\hline Employment, log & 0.891 & 0.898 & 0.911 & 0.912 & 0.603 \\
& $(.010)^{\star \star \star}$ & $(.010)^{\star \star \star}$ & $(.010)^{\star \star \star}$ & $(.010)^{\star \star \star}$ & $(.010)^{\star \star \star}$ \\
Fixed assets, log & 0.121 & 0.120 & 0.111 & 0.120 & \\
Total assets, log & $(.005)^{\star \star \star}$ & $(.005)^{\star \star \star}$ & $(.004)^{\star \star \star}$ & $(.004)^{\star \star \star}$ & \\
& & & & & 0.417 \\
Log employment * OCT10 & & -0.037 & -0.021 & -0.097 & 0.057 \\
& & $(.117)$ & $(.118)$ & $(.089)$ & $(.124)$ \\
Log fixed Assets * OCT10 & & 0.222 & 0.238 & 0.252 & \\
& & $(.068)^{\star \star \star}$ & $(.069)^{\star \star \star}$ & $(.053)^{\star \star \star}$ & \\
Log total Assets * OCT10 & & & & & 0.209 \\
& & & & & $(.093)^{\star \star}$ \\
OCT10 & & -2.100 & -2.353 & -1.951 & -3.068 \\
& & $(.655)^{\star \star \star}$ & $(.661)^{\star \star \star}$ & $(.520)^{\star \star \star}$ & $(.706)^{\star \star \star}$ \\
Constant & 2.526 & 2.506 & 2.571 & 2.503 & 1.597 \\
& $(.072)^{\star \star \star}$ & $(.073)^{\star \star \star}$ & $(.037)^{\star \star \star}$ & $(.048)^{\star \star \star}$ & $(.066)^{\star \star \star}$ \\
Regional dummies & Yes & Yes & No & Yes & Yes \\
Industry dummies & Yes & Yes & No & Yes & Yes \\
Number of observations & 28,511 & 28,511 & 28,511 & 30,954 & 31,631 \\
Number of groups & 13,385 & 13,385 & 13,385 & 14,602 & 14,751 \\
$R^{2}$ & 0.56 & 0.56 & 0.56 & 0.57 & 0.64 \\
\hline
\end{tabular}

Notes: Estimated by the between estimator, robust standard errors in parentheses. All variables are expressed in real terms using GDP deflators. Sample includes manufacturing firms employing 25 people or more, 2006-08. OCT10 is one-company town enterprise dummy (using 10 per cent cut-off). *** indicates significance at 1 the per cent level, ${ }^{* *}$ at the 5 per cent level, and * at the 10 per cent level. 
Table A3. Financial leverage: Long-term debt, $10 \%$ threshold

Dependent variable: Long-term debt-to-assets ratio

\begin{tabular}{lcccc}
\hline \multicolumn{1}{c}{ Tobit estimates } & A & B & C & D \\
\hline Tangibility & $.451^{\star \star *}(.012)$ & $.397^{\star \star *}(.012)$ & $.407^{\star \star *}(.012)$ & $.431^{\star \star *}(.018)$ \\
Employment, log & $.036^{\star \star *}(.002)$ & $.039^{\star \star *}(.002)$ & $.036^{\star \star *}(.001)$ & $.041^{\star \star *}(.003)$ \\
Profitability & $-.079^{* * *}(.022)$ & $-.071^{* * *}(.020)$ & $-.084^{* * *}(.022)$ & $-.064^{* * *}(.021)$ \\
OCT & $.069^{* * *}(.019)$ & $.052^{* * *}(.019)$ & $.030^{*}(.017)$ & $.095^{\star \star}(.036)$ \\
Revenue per employee, log & & & & $.040^{\star \star *}(.003)$ \\
Constant & $-.436^{\star \star *}(.010)$ & $-.351^{\star * *}(.021)$ & $-.414^{\star * *}(.013)$ & $-.515^{\star \star}(.032)$ \\
Regional dummies & No & Yes & Yes & Yes \\
Sector dummies & No & Yes & Yes & Yes \\
Number of observations & 22,715 & 22,715 & 24,845 & 12,633 \\
Pseudo $\mathrm{R}^{2}$ & 0.12 & 0.14 & 0.14 & 0.14 \\
\hline
\end{tabular}

Notes: Estimated by the tobit estimator using averages over 2006-08, standard errors in parentheses. Revenue is expressed in real terms using GDP deflator. Tangibility is the ratio of fixed assets to total assets; profitability is EBIT-to-assets ratio. Sample includes manufacturing firms employing 25 people or more, 2006-08. OCT10 is one-company town enterprise dummy (using 10 per cent cut-off). *** indicates significance at 1 the per cent level, ${ }^{\star \star}$ at the 5 per cent level, and * at the 10 per cent level.

Table A4. Financial leverage: Long-term and short-term debt, 10\% threshold

Dependent variable: Long-term debt-to-assets ratio

\begin{tabular}{lcccc}
\hline \multicolumn{1}{c}{ Tobit estimates } & A & B & C & D \\
\hline Tangibility & $.321^{\star \star *}(.010)$ & $.235^{\star \star *}(.010)$ & $.246^{\star * *}(.010)$ & $.256^{\star \star *}(.014)$ \\
Employment, log & $.032^{\star \star *}(.001)$ & $.033^{\star * *}(.001)$ & $.029^{\star \star *}(.001)$ & $.034^{\star * *}(.002)$ \\
Profitability & $-.180^{* * *}(.052)$ & $-.161^{* * *}(.047)$ & $-.178^{* * *}(.048)$ & $-.141^{* * *}(.054)$ \\
OCT10 & $.065^{* * *}(.018)$ & $.045^{* *}(.018)$ & $.019(.016)$ & $.080^{* *}(.031)$ \\
Revenue per employee, log & & & & $.027^{* * *}(.003)$ \\
Constant & $-.098^{\star \star *}(.010)$ & $-.024(.019)$ & $-.065^{\star * *}(.011)$ & $-.123^{\star * *}(.025)$ \\
Regional dummies & No & Yes & Yes & Yes \\
Sector dummies & No & Yes & Yes & Yes \\
Number of observations & 22,508 & 22,508 & 24,592 & 12,468 \\
Pseudo R & 0.12 & 0.21 & 0.19 & 0.19 \\
\hline
\end{tabular}

Notes: Estimated by the tobit estimator using averages over 2006-08, standard errors in parentheses. Revenue is expressed in real terms using GDP deflator. Tangibility is the ratio of fixed assets to total assets; profitability is EBIT-to-assets ratio. Sample includes manufacturing firms employing 25 people or more, 2006-08. OCT10 is one-company town enterprise dummy (using 10 per cent cut-off). ${ }^{* * \star}$ indicates significance at 1 the per cent level, ${ }^{* \star}$ at the 5 per cent level, and * at the 10 per cent level. 